\title{
Performing the self through social media
}

\section{Caroline Tagg}

Mariza Georgalou 2017. Discourse and Identity on Facebook. London: Bloomsbury, 313 pp. \$135 (HB), ISBN: HB: 978-1-4742-8912-2

Dear politicians, I'm fed up with your dilemmas! The only dilemma I have in 18 degrees sunshine is: coffee break from work in [the Athenian neighbourhoods of] Exarcheia or Monastriaki?

(posted on Facebook by Helen, 24 February at 14:19)

In Discourse and Identity on Facebook, Mariza Georgalou draws powerfully on the voices of her five Greek participants - Helen, Carla, Romanos, Gabriel and Alkis - to make the important argument that, despite the commercial interests that shape the site architecture and constrain user actions, each user's lived experience of Facebook is in part determined by how they perceive the site and choose to exploit it for their own communicative and social ends. As such, the site is shaped as much by users' orientation to external events (such as the unstable political situation in Greece at the time of Georgalou's study) as it is by changes in the site architecture. Georgalou's approach is important in seeing social media primarily as a site for the expression of identity - as she points out, the very creation of a Facebook profile involves identity construction - and as providing a range of semiotic resources on which users can draw in this endeavour, which in turn shape how they convey a sense of self and ultimately who they can be. What emerges most powerfully from the book is thus the value of detailed multimodal semiotic analysis in understanding wider social processes.

Chapter 1 situates the study in a contemporary 'always on' culture in which people move between various digitally mediated and physical spaces in their ordinary daily lives, a phenomenon illustrated by a peek into a day-in-the-life of the author herself. While the author may not be representative of broad swathes of contemporary society, Georgalou is clear throughout the book that she is talking about - and to - a particular segment of society, one that is educated, well-connected and digitally literate. For such users, Facebook provides a rich set of semiotic resources and textual practices which they can exploit to consciously design and con- 
struct particular identities, as well as a space in which identities are performed, 'given off' and negotiated. Underlying this approach is the assumption that discourse constitutes a means perhaps on Facebook the means - of identity construction.

Chapter 2 details Georgalou's understanding of identity not as fixed nor monolithic but as dynamically (re-)mediated through people's discursive practices. This perspective is in line with thinking across language-related fields, including social semiotics and discourse analysis; and one that has proved particularly relevant to the study of identities in virtual environments in which '[a]ll our interactions take place by means of discourse' (p.13). In line with the fact that social network sites typically involve connections between people who already know each other, Georgalou conceptualises identity as discursively co-constructed across the online and offline encounters in which an individual engages, rather than exploring online personae as 'well-established and well-known online identities' in their own right (Varis 2016: 59). This chapter also outlines the 'core experience' of Facebook which, despite ongoing shifts in the site architecture, 'has remained mostly unchanged since its launch' (p.18); although Georgalou's interest is less in the affordances themselves than in how they are taken up.

In Chapter 3, Georgalou lays out the book's methodological approach - a version of discourse-centred online ethnography (Androutsopoulos 2008) - and provides an honest frank account of pragmatic decisions and ethical issues, including her personal involvement with participants and their negotiation of pseudonyms - she rejects one participant's preference, paralias ['the beach guy'] as not serious enough (p.34). Her ethnography blends bi-weekly online observation of Facebook profiles with interactional analysis and ongoing interviews, conducted variously in face-to-face settings and through email and instant messaging (depending on participants' preferences). As Georgalou herself admits, this is not a 'full ethnography' and potentially not even discourse-centred online ethnography as intended, given the focus on one platform. However, this partial ethnography succeeds in showing the particular role of Facebook in individuals' identity performances, even though their performances elsewhere are not given the same treatment.

In Chapters 4 to 8, Georgalou explores various aspects of identity which emerged as salient from her analysis of the interactional data and/or the interviews: place, time, professional and educational identities, stance and privacy. Taking one participant Alkis as an example, throughout these chapters the reader builds up a strong impression of his projected identity, as co-constructed on Facebook and with Georgalou in interview. Alkis was born in 1981 and at the time of the fieldwork was living in Athens; during this time, he completed his MSc in Science Management while unemployed, and worked variously as a project manager, freelance translator and real estate manager, visiting his Facebook profile every day and posting 2-6 times a week. Throughout his Facebook activity, Alkis draws creatively on the embedding of music and other multimodal, multilingual semiotic resources in creating individual and shared identities within a carefully controlled intimate space. 
My interpretation of Georgalou's findings is that Alkis, unlike other participants, sees Facebook primarily as a space for light-hearted banter and bonding, rather than discussing serious or negative issues. He locates himself in the ongoing present and the immediate future, for example, by posting 'long personal emotionally laden wishes' (p. 97) every Christmas and New Year. The unfolding economic crisis in Greece finds its way onto Alkis's Facebook wall, as it does for all participants: but while Helen attends and documents protests and shares political posts, Alkis appears reluctant to engage in talk around the crisis on Facebook: in one lengthy exchange analysed by Georgalou, he repeatedly deflects his friends' negative comments about the political situation, finally suggesting 'If you want to be miserable and cavil do it on my inbox. Not on my wall' (p. 200). Instead of commenting directly on the crisis, he draws on his student identity to express his feelings regarding the situation, particularly regarding being unemployed and needing to make decisions about his future at a time when job opportunities are limited. In doing so, he creates and affiliates to an online community through posts targeted at his fellow students (in one post he labels students struggling with the demands of the MSc in Services Management as 'msmwrecks').

Georgalou shows how, in a space shaped by 'nowness', the past can be an unexpected resource for constructing a coherent identity 'in both personal and collective history' (p. 117) and cultivating and bolstering pre-existing ties. Throughout his posts, nostalgia is performed in response to music, with collective memories of past events prompted by music videos embedded into a post and shared by tagging friends 'in the know'. When Alkis posts a chain message asking friends to reply with one word on how they met, his friends exploit the opportunity to discuss the past at length, drawing on the affordances of chain messaging for their own purposes. As Georgalou concludes, Facebook users create a collective identity not only through the here and now but through remembering and reliving their shared pasts.

One important insight in the book regards the importance of music - specifically music video sharing - to the expression of identity on Facebook. Of the participants, Alkis is most active in posting music videos, and Georgalou shows how his shares contain 'a wealth of stance devices ... to talk about and appreciate the emotional impact of the songs on him' ( $p$. 179). These include appreciate lexis and evaluative adjectives, rhetorical questions and playful mixing of multiple languages: for example, in tres xesiquotique, he transliterates the Greek adjective ksesikotikos ('uplifting') into French by adding the French suffix -que and the French modifier trés ('very') (p. 180). As Georgalou points out, as well as taking stances towards music, Facebook users 'can also take stances through music, and particularly through lyrics, to evaluate a certain state of affairs' (p. 191).

Central to the book is the balance between user agency and structure, which surfaces most clearly in Chapter 8 on privacy and identity. On Facebook, privacy is a process by which users control access to their identity by managing information flows to different segments of their audience. Through discussion of her participants' different approaches to maintaining privacy, 
Georgalou shows how '[p]rivacy is not the same for everyone' (p. 248). While Carla carefully manages distinct segments of her audience by creating two profiles, personal and professional, Alkis is motivated by the danger of strangers coming across his profile ('you don't have to give food for thought to any curious person that ferrets out', p. 229) and the argument that he doesn't need to post information that his Facebook friends already know. As well as tightening his privacy settings, Alkis provides little demographic information in his profile, nor pictures of himself (his profile pictures include a cartoon of an old man burning the midnight oil and a meme alluding to members of Golden Dawn political party): as Georgalou concludes, the expression of identity online is shaped not only by Facebook affordances but by people's own desire to be or not be identified (p. 48). Interestingly, Alkis also sporadically clears his Facebook wall of posts. His actions resonate with my own research into 'context design', whereby Facebook users respond to perceived situational and interactional factors in constructing a context for their online actions which in turn create a particular social space (Tagg et al. 2017). Alkis's ideas about privacy emerged as a result of his experience on the site and his growing frustration with the issue of privacy on Facebook, and his resulting attempts to control his privacy go on to shape his perception and experience of the site: they affect how he comes across to others and the kinds of interactions he can have online.

In Chapter 9, Georgalou summarises the site affordances, semiotic resources and textual practices used on Facebook by these participants to express themselves, highlighting the importance for her participants of creating continuity in identity, whilst also pointing to the disruptive impact that external events - such as the Greek crisis and its ramifications - can have on how users present themselves on the site. This fascinating insight into what Facebook means to these people at this particular time leaves this reader intrigued as to the potential of Georgalou's focus on the networked individual for understanding under-researched demographic groups and for appreciating how identity is constructed across social media platforms.

The book is highly accessible, engaging and clearly written. Key terms in bold italic font are included in a glossary at the end of the book. Each chapter starts with a brief literature review and ends with a couple of largely thought-provoking reflective activities and a discussion of useful resources which goes beyond a mere list. Each analytical chapter also ends with a quick overview of how the author went about the research reported in the chapter, focusing on how the topic emerged as important from her research and on the semiotic resources that formed the basis of her analysis.

\section{REFERENCES}

Androutsopoulos, Jannis 2008. Potentials and limitations of discourse-centred online ethnography. Language@Internet 5, article 9. 
Varis, Piia 2016. Digital ethnography. In: Alexandra Georgakopoulos and Tereza Spilioti (eds) The Routledge handbook of language and digital communication. Abingdon: Routledge, pp. 55-68.

Tagg, Caroline, Philip Seargeant and Amy Aisha Brown 2017. Taking offence on social media: conviviality and communication on Facebook. London: Palgrave.

Caroline Tagg is Senior Lecturer in Applied Linguistics, Faculty of Wellbeing, Education \& Language Studies, School of Languages and Applied Linguistics, The Open University, United Kingdom.

Email: caroline.tagg@open.ac.uk 